DOI : https://doi.org/10.24123/jbt.v5i2.4724

\title{
BUSINESS SUSTAINABILITY: HOW TO ENGAGE CUSTOMERS DURING THE PANDEMIC
}

\author{
Devi Rachmasari \\ Politeknik UBAYA; Surabaya, Indonesia \\ Email : devi@staff.ubaya.ac.id
}

\begin{abstract}
It is a worldwide condition that corona virus spread at the end of 2019. The lockdown policy applied in most countries in the world as an effort to break the chain of spread of the virus, unfortunately, has a big impact on economics activities. The business must think hard in order to be able to sustain. Thus the writer wants to analyze a case in a language course in Surabaya to be able to survive and engage customers during the pandemic by using descriptive qualitative study with a case study. The strategy of new mindset and digital marketing is proved to be effective in making the course sustains during the pandemic of covid 19. The long distance and lockdown condition is no longer a matter since through digital marketing, the course is able to reach the public to be customers.
\end{abstract}

Keywords: business, sustainability, strategy, customers, pandemic

\section{Intoduction}

The covid 19, also known as the Coronavirus 2019, spreaded into Indonesia since early of March 2019. Sirkeci and Yucesahin (2020) described the virus as a type of virus that harms the respiratory system and has contaminated more than 15 million people worldwide from more than 200 confirmed countries.

In order to cut the chain of the spread of the virus, the Indonesian government officially released a partial physical lockdown policy since mid of March 2020. The Indonesian government enforced this social distance policy nationally. This decision is part of joining the international community's collective response to the threats of a corona virus. People believed the corona virus spread in public places, crowded places for example: markets, shopping center, school, universities, houses of worship, etc. The condition leads to other difficulties such as economic decrease, job loss, and other risks for both government and public business, national and global.

Thus, the business enterprise must rethink their strategy in order to make the business run during the pandemic. 


\section{Literature Review Sustainable Business}

A sustainable business strategy defined as a combination of business targets and the social environment that has integrated into the business targets, operations, management, and business planning that has established towards long-term business sustainability (Fernando et al., 2019).

Shen (2010) describes business sustainability as the key to business success for a moment and its sustainability and the corporate social environment. Consequently it is significant to create strong business management that has an easy-to-apply approach.

Arief et al (2021) mentioned that a company must prioritize a new mindset strategy in difficult times for business due to Covid-19. It is the mindset of business that they must change to be able to adapt to new conditions and be ready entering new normal conditions as well as after the Covid-19. By having the right mindset, there will be an opportunity for businesses to be able to remain sustainable.

\section{Digital Marketing}

Narulia (2019) stated digital marketing is a way to market products through technology. Digital marketing is proved to be able to increase selling power of a business. Pradiani (2017) also mentioned that the use of social media is able to increase the selling of souvenirs made by small business. Furthermore the digital marketing used may various from whatsapp, instagram, facebook and other social media. These social medias give easiness in marketing the products of a business and reaching customers. In nowadays digital era, digital marketing can create a horizontal line of customers by web. This will increase the engagement of a company and customers.

\section{Social Media Marketing}

The new breakthrough in this period is social media marketing where people have access into social media (Gray and Fox, 2018). With social media, the business owner can promote company's products and services as we known as marketing, in different manner where everyone can reach the products and services. Gray and Fox (2018) also mentioned that social media is a breakthrough because it has different layout which is able to give some option to the business owner to create promotional campaigns for the business.

According to Rahadi and Zainal (2016), social media marketing is a strategy of marketing techniques and processes that the use social media as a means to promote products or services. Indeed, there are many familiar social media marketing for public, for example facebook, instagram, twitter, youtube, pinterest, reddit, etc. Morever, each social media has different procedure of usage. As we can see in instagram that only has feature to share photo and video which can be added with descriptions, links, tags and hashtags.

\section{Instagram Marketing}

Tran (2016) said that instagram (a portmanteau of Instant Telegram) is a mobile application that permit its users to do many interesting action such as take, upload, and even more edit photos and videos on the go. The most interesting thing is that instagram also offers social networking. It allows its users to share content with their followers or a circle of people such as comment or like on what people's posts (both photos and videos) on their instagram account. Thus people can see and comment on others. This fascinating condition lead people engage to each other, even from unknown seller to reach its 
potential buyers. Moreover, recently instagram has developed from "nice-to-have" to "need-to-have" for the most effective social marketers. Instagram is no longer just a photo/ video sharing platform. But it is now considered as the "King of Social Engagement" in the commercial world.

It is stated by Santoso, Baihaqi, \& Persada (2017) that instagram marketing gives recognition, awareness, memory and even an action against a brand, product, business, person or group, by using social web tools such as Instagram, directly or indirectly. It means that this social media, named instagram, has been evolved into a very creative way of marketing that a company prefer to use. Indeed, we can say that instagram is a new breakthrough when such a social media platform which originally is utilized for communication, but later it is transformed to be marketing tools which can reach infinite audiences around the world, and possibly attract potential buyers to sellers or business.

In order to give better understanding about instagram, some features that belongs to Instagram are as follow:

1. Account name: It is the name of the account that people usually search and see to get into the account page. This account name is unique and different from other users.

2. Logo or profile picture: It is the picture of an account that people usually pay attention to identify whether an account is real or not. There may be similar account name, but picture can identify an account.

3. Company name: company name is different from an account name. An account name can be thought as a nickname but a company name is the full name of the account.

4. Company description: this field is a place to put all information to describe what type of a company or an account that offers. The description itself varies from the location of the company, the contact person of the company, the important link etc.

5. Profile edit: this is the feature where all of the above features can be edited or made into the preference of the company.

6. Post a picture: this is a feature that an account can post a content that can be seen to its followers and other users.

7. Insight: this is a feature for Instagram business user that people can see the account's potential and engagement with users. This is also data of content interaction, impression, and follower breakdown can be found.

8. Account feed: it is a segment that a user can see all the contents that have been posted, and this is the statement of an account image where people can see and interact

9. Homepage: it is the content of people that user follows

10. Search Bar: it is a feature which people can search an account name that people are looking for

11. Post a content: it is a feature that an account is able to post a content that can be seen to its followers and other users.

12. Account page: it is a feature that a user can see his / her own profile and access all the features described above.

13. Instagram story: It is a brief clip of pictures or short video that can be accessed when people do not have sufficient time to look at the content in the instagram feed. This instagram story feature is a significant feature that can boost up engagement with user. 


\section{Methods}

This study is a descriptive qualitative study using a case study approach that describes the sustainability strategy of a language center in Surabaya in its effort to engage customers during the early time of the pandemic in April 2019-December 2020. The data collection was conducted through participative observation, deep interviews with employees and documents review. The analysis was conducted by data reduction from observation explored in a report, then reduced until produced better data. The internal validity was carried out trough triangulation. The writer compared the data obtained from observation, interview and document, in order to get the accuracy of the data.

\section{Results and Discussions}

The writer analyzed a language course in Surabaya that supported by $20 \%$ administration staffs and $80 \%$ teachers. $90 \%$ of customers of the course were students that study in the university, while $10 \%$ were students of high school and employees.

The immediate lockdown regulation in mid March 2019 really shocked the course. The government regulation said that it is obligatory to close education institutions since students usually tend to gather, and it is needed to be avoided as it will cause the virus easily to spread. While this happened, it was in the mid period of the teaching and learning process. The condition really hits the course due to before the pandemic, everything of the business runs offline, it can say $100 \%$ of the business operates offline, start from administration process, promotion, teaching and learning activity until evaluation. Consequently, in order to make the business sustain, the course must rethink the new strategy. The option is significantly challenging, dare to change or the business will end.

\section{A New Mindset}

The lockdown regulation led the teaching and learning process which hasn't finished yet, to be stopped. As customers must get their rights for the complete teaching and learning process, the course needs to act immediately, to continue the teaching and learning process in an alternative ways. It is not such an easy way. The human resources of the course, need to understand the condition, specifically, need to prepare and be ready for anything in responding to impact of the lockdown circumstances due to the pandemic of covid 19.

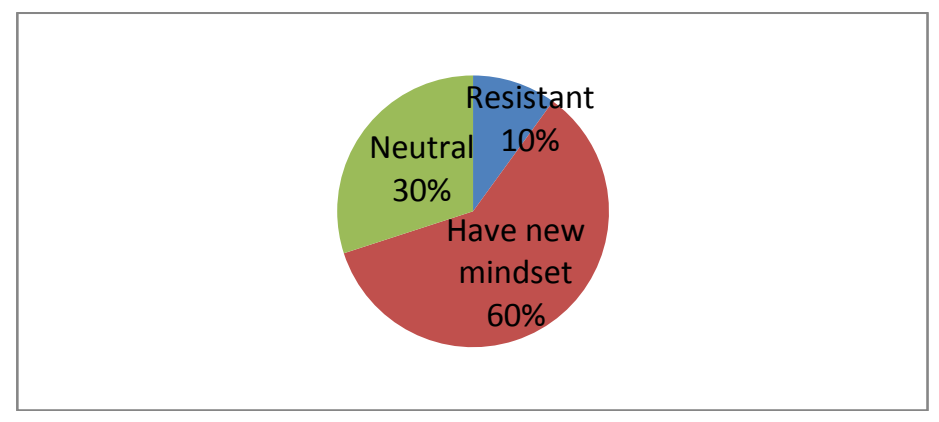

Figure 1. The new mindset condition of human resources

From the figure above we can notice that $60 \%$ of the human resources were aware of the condition and have a new mindset to adapt to the change, $30 \%$ were neutral, while $10 \%$ were resistant to adapt and change. 
Adjusting a new mindset during the pandemic of covid 19, is not easy. Some of them saw the pandemic may last in couple of months. Indeed, looking back to the history, it told that worldwide pandemic in the past at least occurred within two years. Thus the course must convert the teaching and learning process into online course, in order to fulfill the responsibility to the students.

The course step by step prepares the readiness of the neutral ones, and force the resistant one, to be ready to adapt to the new normal condition and shift everything to be online. It is done by informing the update condition of the pandemic from the government, training to use digital technology (for example zoom, google meet, google classroom, google documents/form, mentimeter, padlet etc) and preparing online infrastructure.

The Covid-19 should not be considered as difficult situation, but more as a case to be learned and solved. The proper mindset need to be learnt to set the business keep running.

\section{Digital Marketing}

In order to reach customers during the pandemic, that most people stay at home in order to cut the spread of the disease, the course moved the promotion of the brand as well as the service of the course from offline promotion into online promotion, known as digital marketing. This way of marketing using technology, is able to reach customers broadly.

The course's online advertisement is by putting much content to the internet. Thus, it can be discovered by the customers whenever they are online.

\section{Instagram Marketing}

The type of digital marketing used by the course is social media marketing, specifically instagram, since most of the customers of the course are university students and some school students, as this generation mostly use and have their own social media. Instagram marketing is able to attract people who are online to visit the instagram of the course and then take a look at the content. The content consist of some information related to the course program (opening of the course, test program), tips and trick in learning foreign languages, common grammar mistakes, and many more. This content can make people who are interested on it, finally follow the instagram account of the course. Indeed, these followers are prospect customers who are able to get notification whenever the course uploads new content in the instagram.

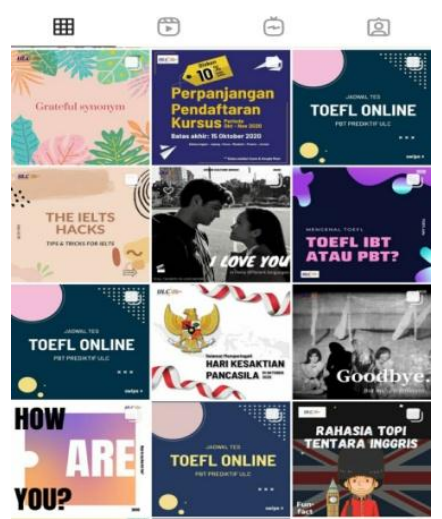

Figure 2. Example of social media marketing conducted by the course 
Figure 2 shows the content of the instagram feed of the course. The content itself is made to suit the interest of target consumers of the course in order to engage the customers. The feed made as thematic content so the appearance is both attractive and informative. The feed is about tips related to language study, for example IELTS hacks, phrases in daily communication, and many more. Among those tips, the course puts the promotion of the course, for example the schedule of online TOEFL Test, the registration of the course, etc.

This instagram promotion is effective since whenever public especially followers access their instagram account, they will be able to see the content of the course. If they are interested to join or ask further information, all they need is just click the link and they will be connected with the administration staff of the course. Indeed, the lockdown condition is no longer problem since the course now is able to engage with customers wherever the customers are.

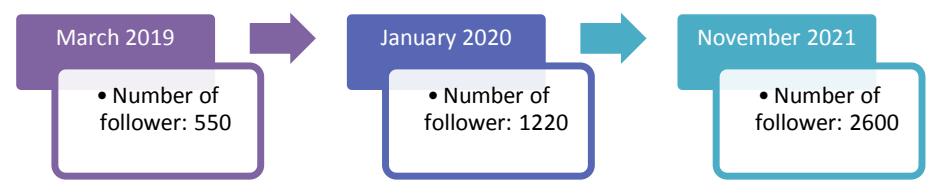

Figure 3. Number of followers that can be reached

From figure 3 we can see that the number of the instagram followers of the course increase year by year, from 550 followers in March 2019 to 1220 followers in January 2020, and 2600 followers in November 2021. It means public are interested in the both the course's program and content. The higher the number of the instagram followers of the course, the higher opportunity to gain customers of the course. 


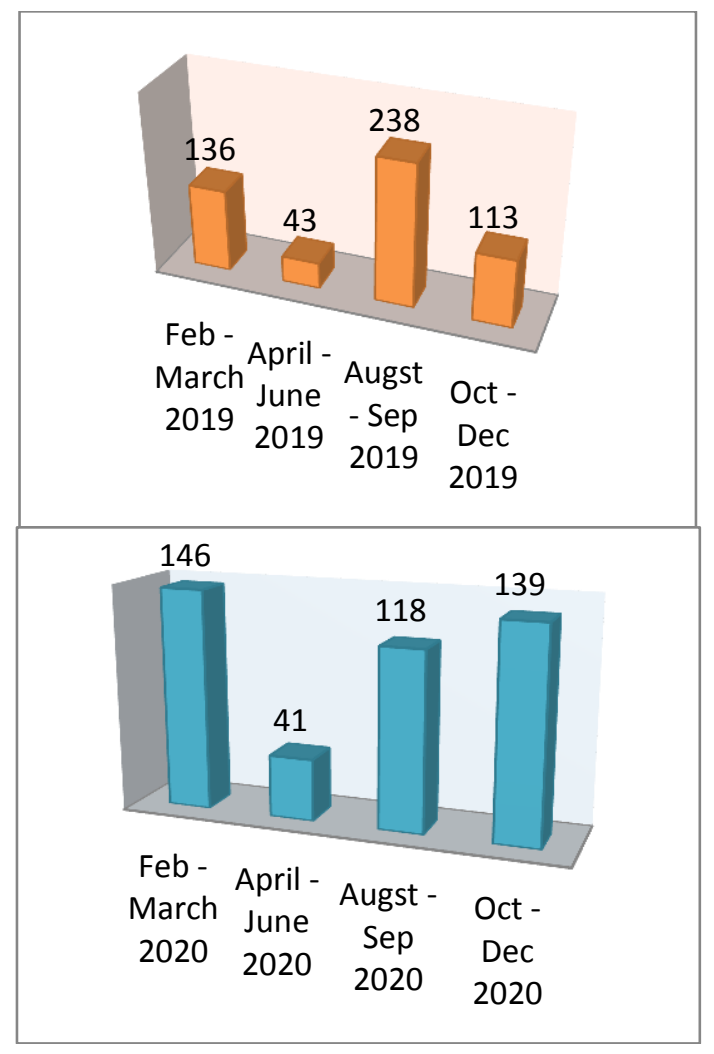

Figure 4. Number of customers joint the course in Feb 2019 - Dec 2020

We can see the effectiveness of instagram marketing of the course in engaging customers from figure 4 . It shows that the numbers of participants of the course are maintained well even though it is in the pandemic of covid 19. The number of participants is still maintained around more than one hundred through 2019-2020. Moreover, the top is in August-September 2019 that the numbers of participants of the course is 238. The decrease number of participants occurred in April-June in both 2019 and 2020, since it was fasting month and Eid Mubarak time, as we understand people tend to focus more in worship.

\section{Conclusion}

The strategy of new mindset and digital marketing is proved to be effective in making the course sustains during the pandemic of covid 19. The long distance and lockdown condition is no longer a matter since through digital marketing, the course is able to reach the public to be customers.

The new mindset, lead the human resources to be ready with the new normal era and push themselves to shift to digital technology in many aspects of the course operation, start from the online promotion until teaching and learning process. Thus, both combination of new mindset and digital marketing lead the course to be able in maintain the numbers of the participants, and we can say to be able to sustain during the pandemic. 


\section{References}

Arief, A. S., Mulyadi, M., \& Liriwati, F. Y. 2021. The sustainable business strategy during the new normal era: lesson for Indonesian academic. International Research Journal of Management, IT and Social Sciences, 8(3), 274- 285. https://doi.org/10.21744/irjmis.v8n3.1667

Fernando, Y., Jabbour, C. J. C., \& Wah, W. X. 2019. Pursuing green growth in technology firms through the connections between environmental innovation and sustainable business performance: does service capability matter? Resources, $\begin{array}{llll}\text { Conservation } \quad \text { Recycling, } & \text { 8-20. }\end{array}$ https://doi.org/10.1016/j.resconrec.2018.09.031

Gray, N., Fox, M. 2018. Social Media Step by Step Instructions For Step by Step For Advertising Your Business on Facebook, Youtube, Instagram, Twitter, Pinterest, Linkedin and Various Other Platforms. San Benardino: CreateSpace Independent Publishing Platform

Narulia, Ria Zulkha E. and Hanjar Ikrima Nanda.2019. Digital Marketing Sebagai Strategi Pemasaran. Jurnal Pengabdian Untuk Mu NegeRI 3(2): 80-84.

Pradiani, Theresia. 2017. Pengaruh Sistem Pemasaran Digital Marketing Terhadap Peningkatan Volume Penjualan Hasil Industri Rumahan. JIBEKA 11(2): 46-53.

Rahadi, D.R., Zainal. 2016. Social Media Marketing dalam Mewujudkan E-marketing. Konferensi Nasional Teknologi dan Aplikasinya (p.71). Palembang: Universitas Sriwijaya

Santoso, A. P., Baihaqi, I., \& Persada, S. F. 2017. Pengaruh Konten Post Instagram terhadap Online Engagement: Studi Kasus pada Lima. JURNAL SAINS DAN SENI ITS, VI(1), 50-54.

Santoso, Rudi 2020. Review of Digital Marketing \& Business Sustainability of ECommerce During Pandemic Covid19 In Indonesia. Jurnal Ilmu Ekonomi Terapan, 5(2), 36-48. https://e-journal.unair.ac.id/JIET

Shen, L., Tam, V. W. Y., Tam, L., \& Ji, Y. 2010. Project feasibility study: The key to successful implementation of sustainable and socially responsible construction management practice. Journal of Cleaner Production, 18(3), 254-259. https://doi.org/10.1016/j.jclepro.2009.10.014

Sirkeci, I., \& Yucesahin, M. M. 2020. Coronavirus and Migration: Analysis of Human Mobility and the Spread of Covid-19. Migration Letters, 17(2), 379-398. https://doi.org/10.33182/ml.v17i2.935

Tran, M. 2016. An Instagram is worth a thousand words. The utilizationof Instagram as a key social media marketing strategy. Case: Valona Design. Bachelor Thesis Degree Program In International Business: University of Applied Sciences 